\title{
Seafloor Characteristics in the Azores Region (North Atlantic)
}

\author{
Antonio D. Peran, Christopher K. Pham *, Patrícia Amorim, Frederico Cardigos, \\ Fernando Tempera and Telmo Morato \\ MARE-Marine and Environmental Sciences Centre and IMAR - Institute of Marine Research, University of the Azores, Horta, \\ Portugal
}

Keywords: Azores, seafloor characteristics, bathymetry, deep sea, geomorphology, GIS dataset

\section{OPEN ACCESS}

Edited by:

Anna Metaxas,

Dalhousie University, Canada

Reviewed by:

Mustafa Yucel,

Middle East Technical University,

Turkey

Katleen Robert,

National Oceanography Centre, UK

${ }^{*}$ Correspondence:

Christopher K. Pham

phamchristopher@gmail.com

Specialty section

This article was submitted to

Deep-Sea Environments and Ecology,

a section of the journal

Frontiers in Marine Science

Received: 05 July 2016

Accepted: 30 September 2016

Published: 20 October 2016

Citation:

Peran AD, Pham CK, Amorim P, Cardigos F, Tempera F and Morato $T$ (2016) Seafloor Characteristics in the

Azores Region (North Atlantic).

Front. Mar. Sci. 3:204.

doi: 10.3389/fmars.2016.00204
Current European legislation such as the Marine Strategy Framework Directive (MSFD; 2008/56/EC) has highlighted the need for accurate maps on the geomorphology of Europe's maritime territory. Such information is notably essential for the production of habitat maps and cumulative impact assessments of human activities (Halpern et al., 2008) necessary for marine spatial planning initiatives (Gilliland and Laffoley, 2008) and assessments of the representativity/sufficiency of marine protected areas networks like Natura 2000. Broadscale satellite bathymetry presently allows the identification of all prominent geomorphic structures present on the seafloor with a high grade of accuracy. However, these datasets and maps still need to be more widely disseminated in the scientific community.

In this contribution, we provide an inventory of some important datasets related to the physical characteristics of the seafloor surrounding the Azores Archipelago. The objective is to ensure that our compilation is readily available for any researchers interested in developing species distribution models, or for the management and conservation of natural resources in the region.

In total, we produced and compiled 18 layers of seabed characteristics for the Azores region (Table 1), deposited at Pangaea, Data Publisher for Earth and Environmental Science (Perán Miñarro et al., 2016).

The Azores area is located in the North Atlantic Ocean between $28^{\circ} 00^{\prime} \mathrm{N}-49^{\circ} 00^{\prime} \mathrm{N}$, and $17^{\circ} 00^{\prime} \mathrm{W}-41^{\circ} 00^{\prime} \mathrm{W}$ with an extension of approximately $8,051,544 \mathrm{~km}^{2}$ that includes the Exclusive Economic Zone (EEZ) along with the Portugal's claimed extended continental shelf area around the archipelago (Figure 1).

Several seafloor geomorphic variables were produced through the different geoprocessing tools: Slope, Aspect, Northness, Eastness, Vector Ruggedness Measure (VRM), Plan Curvature, Profile Curvature, Total Curvature, Surface-area, Surface-ratio, Hillshading, MDOW-Hillshade (Multidirectional Oblique-Weighed) and broad/fine scale Bathymetric Position Index (BPI). All these bathymetric derivatives (Table 1) were based on the Global Bathymetry and Elevation Data at 30 Arc Seconds Resolution (SRTM30_PLUS; Becker et al., 2009) and computed in ArcGIS using a combination of two geoprocessing add-ons; Benthic Terrain Modeler (Wright et al., 2005) and Digital Elevation Model Surface Tools (Jenness, 2004).

Using SRTM30_PLUS (Figure 1A), we also provide a layer that delimits the depth-based biological zones proposed by Howell (2010). Four different biological zones were mapped: sublittoral ( $0.05 \%$ of the seafloor in our study area), upper slope $(0.29 \%)$, upper bathyal $(0.42 \%)$, mid bathyal (2.95\%), lower bathyal (9.94\%), and abyssal (86.28\%).

The diversity of the different geomorphologic structures present in the study area (Figure 1B) was obtained through the recently completed digital Global Seafloor Geomorphic Features Map (GSFM; Harris et al., 2014).

In their study, Harris et al. (2014) present seafloor geomorphology as a hierarchy of base layers for the shelf, slope, abyss and hadal zones, which are further divided into classification layers and discrete feature layers, sometimes overlaying each other. The Azores area considered 
TABLE 1 | Layers on the characteristics of the seafloor in the Azores.

\begin{tabular}{|c|c|c|c|}
\hline Layer & Description & Source & Processing tool \\
\hline Bathymetry & Seafloor depth & SRTM30_PLUS & - \\
\hline Slope & Maximum seafloor depth gradient & SRTM30_PLUS & DEM Tools \\
\hline Aspect & Direction of maximum slope & SRTM30_PLUS & DEM Tools \\
\hline Northness & Orientation of the slope (cosine of aspect) & SRTM30_PLUS & $\begin{array}{l}\text { Benthic Terrain } \\
\text { Modeler }\end{array}$ \\
\hline Eastness & Orientation of the slope (sine of aspect) & SRTM30_PLUS & $\begin{array}{l}\text { Benthic Terrain } \\
\text { Modeler }\end{array}$ \\
\hline $\begin{array}{l}\text { Vector Ruggedness Measure } \\
\text { (VRM) }\end{array}$ & Index reflecting the variability of slope and aspect in a single measure & SRTM30_PLUS & $\begin{array}{l}\text { Benthic Terrain } \\
\text { Modeler }\end{array}$ \\
\hline Plan Curvature & $\begin{array}{l}\text { Variable representing the concave, convex or linear profile of the substrate } \\
\text { perpendicularly to the slope. A positive value indicates the surface is } \\
\text { sidewardly convex at that cell, while negative values indicate the surface is } \\
\text { sidewardly concave. A value of zero indicates the surface is flat } \\
\text { across-slope. PIC emphasizes convergence and divergence of } \\
\text { along-slope flows }\end{array}$ & SRTM30_PLUS & DEM Tools \\
\hline Profile Curvature & $\begin{array}{l}\text { Profile curvature is extracted along to the direction of the maximum slope. } \\
\text { A negative value on a given cell indicates that the surface is upwardly } \\
\text { concave. Instead, positive values indicate surfaces that are upwardly } \\
\text { convex. A value of zero indicates that the surface is linear (i.e., slope does } \\
\text { not change along-slope). PrC emphasizes the ridges, valleys and terraces } \\
\text { on a surface. It is also an indicator of the acceleration and deceleration of } \\
\text { gravitational flows, which influences erosion and deposition processes }\end{array}$ & SRTM30_PLUS & DEM Tools \\
\hline Total Curvature & $\begin{array}{l}\text { Total curvature or general curvature is the second derivative of the surface } \\
\text { (or the slope-of-the-slope). It is extracted on a cell-by-cell basis taking into } \\
\text { account its eight surrounding neighbors. It considers both plan and profile } \\
\text { curvature together, permitting a more accurate understanding of flow } \\
\text { patterns across a surface }\end{array}$ & SRTM30_PLUS & DEM Tools \\
\hline Surface-area ratio & $\begin{array}{l}\text { Seafloor topographic roughness/irregularity index calculated by dividing } \\
\text { the surface area value of a gridcell (taking into account its slope gradient) } \\
\text { by its planimetric area }\end{array}$ & SRTM30_PLUS & DEM Tools \\
\hline $\begin{array}{l}\text { Bathymetric Position Index (BPI) } \\
\text { (Broad-scale) }\end{array}$ & $\begin{array}{l}\text { The BPI is a measure of where a referenced location is relative to the } \\
\text { locations surrounding it. The BPI is derived from an input bathymetric data } \\
\text { set and itself is a modification of the topographic position index algorithm } \\
\text { that is used in terrestrial environment. The Broad-scale BPI (inner radius of } \\
25 \text { and outer radius of 250) identifies larger features within the seafloor }\end{array}$ & SRTM30_PLUS & $\begin{array}{l}\text { Benthic Terrain } \\
\text { Modeler }\end{array}$ \\
\hline $\begin{array}{l}\text { Bathymetric Position Index (BPI) } \\
\text { (Fine-scale) }\end{array}$ & $\begin{array}{l}\text { The BPI is a measure of where a referenced location is relative to the } \\
\text { locations surrounding it. The BPI is derived from an input bathymetric data } \\
\text { set and itself is a modification of the topographic position index algorithm } \\
\text { that is used in terrestrial environment The Fine-scale BPI (inner radius of } 5 \\
\text { and outer radius of 25) identifies smaller features within the seafloor }\end{array}$ & SRTM30_PLUS & $\begin{array}{l}\text { Benthic Terrain } \\
\text { Modeler }\end{array}$ \\
\hline Hillshading & $\begin{array}{l}\text { Sun-illuminated relief representation computed using a single illumination } \\
\text { angle }\end{array}$ & SRTM30_PLUS & DEM Tools \\
\hline $\begin{array}{l}\text { MDOW-Hillshade } \\
\text { (Multidirectional } \\
\text { Oblique-Weighled) }\end{array}$ & $\begin{array}{l}\text { Advanced sun-illuminated relief representation computed using } \\
\text { illumination simulations from multiple angles }\end{array}$ & SRTM30_PLUS & DEM Tools \\
\hline Classified depth zones & $\begin{array}{l}\text { Depth zones segmentation using Howell (2010) thresholds (littoral, upper } \\
\text { slope, upper bathyal, mid bathyal, lower bathyal, abyssal) }\end{array}$ & SRTM30_PLUS & - \\
\hline Geomorphic features & $\begin{array}{l}\text { Delimitation of the different geomorphic structures present in the region } \\
\text { (abyss, basin, canyon, escarpment, plateau, ridge, rift-valley, rise, shelf, } \\
\text { through) }\end{array}$ & Harris et al., 2014 & - \\
\hline Substrate type & Seafloor substrate type & Multiple (see text) & - \\
\hline Sediment thickness & Sediment thickness of the seafloor & Divins (2003) & - \\
\hline
\end{tabular}




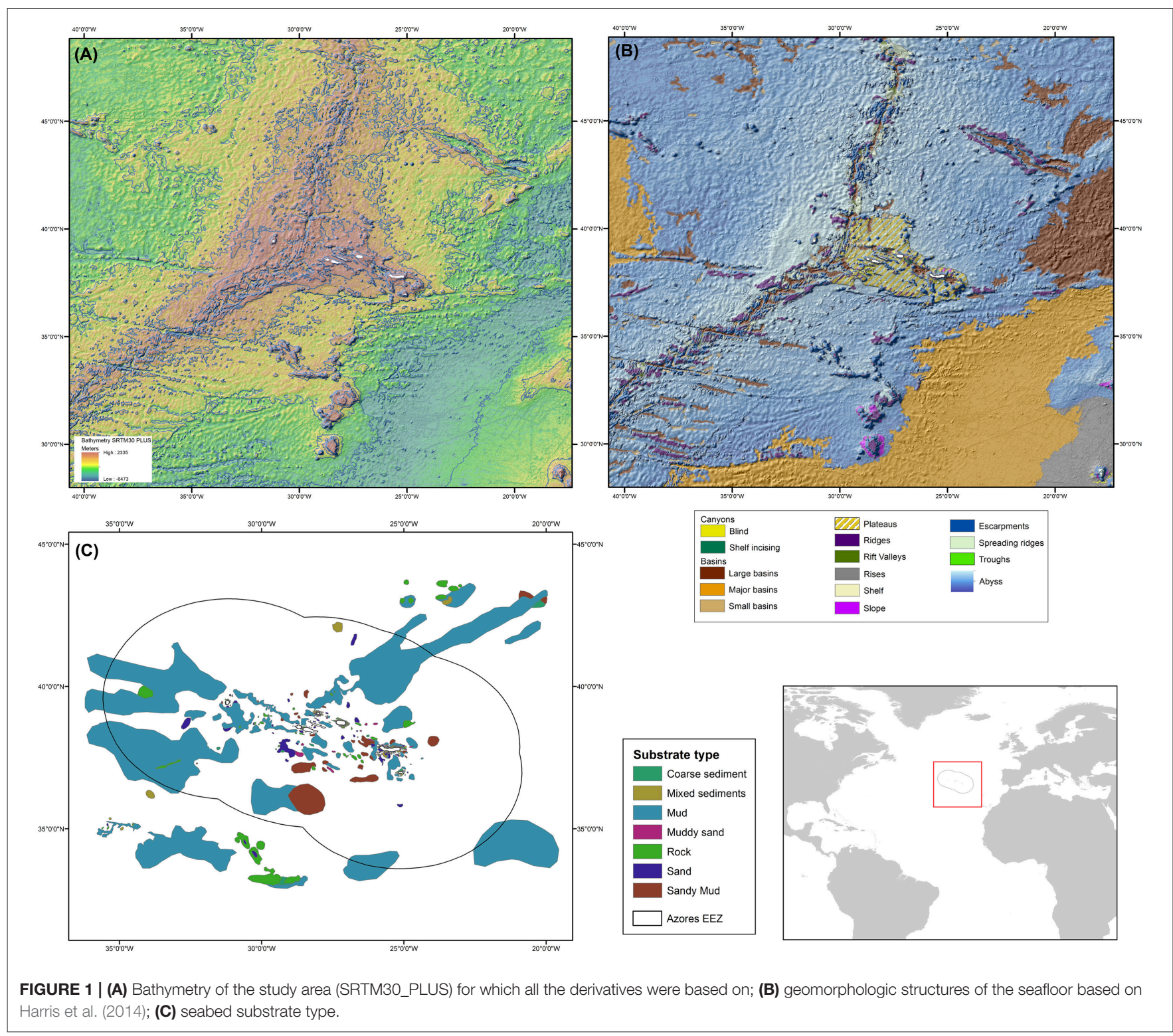

in this study encompasses the following layers: the base layer abyss (representing $99.1 \%$ of the study area and subdivided into abyssal plains, abyssal hills and abyssal mountains) and the following discrete feature layers: basin (22.72\%), canyon (0.14), escarpment (7.35\%), plateau (2.91\%), ridge (3.95\%), rift-valley $(0.63 \%)$, spreading ridges $(3.4 \%)$, shelf $(0.04 \%)$ and through (0.54\%).

Seabed substrate type (Figure 1C) were based on different sources: multibeam backscatter and seismic surveys, point data digitized from up-to-date and historical nautical charts for the Azores and data provided by the World Seabed Data Browser, the Lamont-Doherty Earth Observatory and National Geophysical Data Center (NGDC). Since most of the information was available as sample point data, a geologic interpretation of seafloor type around the Azores was undertaken (collaboration with IEO researchers: José Luis Sanz Alonso and Dulce Mata Chacón) using the seafloor point data and bathymetry information. This approach was later complemented by statistical modeling (Multinomial regression models) using other terrain variables (e.g., Bathymetry, Slope, Eastness, Northness, Rugossity) to cover the uninterpreted areas left by the expert (Mata Chacón et al., 2013; Vasquez et al., 2015). The expert geological interpretation of seabed sampled points was given priority in the final mosaic of the substrate types for the Azores region. The output resulted in the compilation of the highest resolution seabed substrate data available: an interpreted and modeled substrate layer with a $250 \mathrm{~m}$ resolution. The area covered by the seabed substrate layer is more limited than the total area considered in this study. 
A specific analysis of the sediment thickness characteristics of the Azores area was undertaken using the "Total Sediment Thickness of the World's Oceans and Marginal Seas, Version 2" (Whittaker et al., 2013), an updated dataset from the original global National Geophysical Data Centre (NGDC) sediment grid (Divins, 2003). The new total sediment thickness grid can be found at the National Geophysical Data Center's website (https:// www.ngdc.noaa.gov/mgg/sedthick/index.html).

The compilation of the seabed characteristics for the Azores and surrounding areas in North Atlantic is part of a larger effort to assemble as much data on the environmental characteristics of this region (e.g., Amorim et al., in press), to improve our knowledge and facilitate the development of future integrated studies.

\section{AUTHOR CONTRIBUTIONS}

TM, CP, FC, and FT designed the study. PA, ADP, and FT collected and processed most of the data through GIS software. TM, CP, PA, and ADP performed most of the analyses. PA, ADP, $\mathrm{CP}, \mathrm{FC}, \mathrm{FT}$, and TM wrote the paper.

\section{REFERENCES}

Amorim, P., Perán, A. D., Pham, C. K., Cardigos, F., Tempera, F., T., and Morato (in press). Overview of the ocean climatology and its variability in the Azores region of the North Atlantic including environmental seabed characteristics. Front. Mar. Sci.

Becker, J. J., Sandwell, D. T., Smith, W. H. F., Braud, J., Binder, P., Depner, J., et al. (2009). Global bathymetry and elevation data at 30 arc seconds resolution: SRTM30_PLUS. Mar. Geod. 32, 355-371. doi: 10.1080/014904109032 97766

Divins, D. L. (2003). Total Sediment Thickness of the World's \& Oceans Marginal Seas. Boulder, CO: NOAA National Geophysical Data Center.

Gilliland, P. M., and Laffoley, D. (2008). Key elements and steps in the process of developing ecosystem-based marine spatial planning. Mar. Pol. 32, 787-796. doi: 10.1016/j.marpol.2008.03.022

Halpern, B. S., Walbridge S., Selkoe K. A., Kappel, C. V., Micheli, F., D’Agrosa, C., et al. (2008). A global map of human impact on marine ecosystems. Science 321, 1444-1445. doi: 10.1126/science. 1149345

Harris, P. T., Macmillan-Lawler, M., Rupp, J., and Baker, E. K. (2014). Geomorphology of the oceans. Mar. Geol. 352, 4-24. doi: 10.1016/j.margeo. 2014.01.011

Howell, K. L. (2010). A benthic classification system to aid in the implementation of marine protected area networks in the deep/high seas of the NE Atlantic. Biol. Cons. 143, 1041-1056. doi: 10.1016/j.biocon.2010. 02.001

Jenness, J. S. (2004). Calculating landscape surface area from digital elevation models. Wildl. Soc. Bull. 32, 829-839. doi: 10.2193/00917648(2004)032[0829:CLSAFD]2.0.CO;2

Mata Chacón, D., Sanz Alonso, J. L., Gonçalves, J. M. S., Monteiro, P., Bentes, L., McGrath, F., et al. (2013). Report on Collation of Historic Maps. Bathymetry, Substrate and Habitats - MeshAtlantic Report. Spanish Institute

\section{FUNDING}

This research received funding from Fundo Regional da Ciência, Tecnologia (FRCT), through the research project 2020-M2.1.2/I/026/2011 (Pro-Convergência), and the European Union Seventh Framework Programme (FP7/2007-2013) under the MIDAS project, grant agreement 603418 and Interreg project MeshAtlantic (AA-10/1218525/BF). The authors also acknowledge funds provided by the Fundação para a Ciência e a Tecnologia (FCT) through the strategic project (FCT/UID/MAR/ 04292/2013) granted to MARE. TM is supported by Program Investigador FCT (IF/01194/2013) and IFCT Exploratory Project (IF/01194/2013/CP1199/CT0002), PA is currently supported by a FCT Ph.D grant (SFRH/DB/103504/2014) and was previously co-financed by project MeshAtlantic (AA-10/1218525/BF), FT was supported by a post-doc grant from the FCT (ref. SFRH/ BPD/79801/2011), ADP was partially supported by the Estagiar L program from the Government of the Azores, and FC was supported by IMAR and the European Marine Observation and Data Network through contract IMAR/EMODnet Biology/0012014.

of Oceanography. Available online at: http://www.meshatlantic.eu/assets/files/ MeshAtlantic_Report_Collation.pdf

Perán Miñarro A. D., Pham, C. K., Amorim P., Cardigos F., Tempera F., Morato T. (2016) GIS Layers of Seafloor Characteristics in the Azores Region (North Atlantic), Links to Files in ArcGIS Format. PANGAEA. doi: 10.1594/PANGAEA.862152

Vasquez, M., Chacón, D. M., Tempera, F., O’Keeffe, E., Galparsoro, I., Alonso, J. L. S., et al. (2015). Broad-scale mapping of seafloor habitats in the northeast Atlantic using existing environmental data. J. Sea Res. 100, 120-132. doi: 10.1016/j.seares.2014.09.011

Whittaker, J., Goncharov, A., Williams, S., Dietmar Müller, R., and Leitchenkov, G. (2013). Global sediment thickness data set updated for the AustralianAntarctic Southern Ocean. Geochem. Geophys. Geosyst. 14, 3297-3305. doi: 10.1002/ggge.20181

Wright, D. J., Lundblad, E. R., Larkin, E. M., Rinehart, R. W., Murphy, J., CaryKothera, L., et al. (2005). ArcGIS Benthic Terrain Modeler. Corvallis, Oregon, Oregon State University, Davey Jones Locker Seafloor Mapping/Marine GIS Laboratory and NOAA Coastal Services Center. Available online at: https://coast. noaa.gov/digitalcoast/tools/btm

Conflict of Interest Statement: The authors declare that the research was conducted in the absence of any commercial or financial relationships that could be construed as a potential conflict of interest.

Copyright (C) 2016 Peran, Pham, Amorim, Cardigos, Tempera and Morato. This is an open-access article distributed under the terms of the Creative Commons Attribution License (CC BY). The use, distribution or reproduction in other forums is permitted, provided the original author(s) or licensor are credited and that the original publication in this journal is cited, in accordance with accepted academic practice. No use, distribution or reproduction is permitted which does not comply with these terms. 